\title{
Identifikasi Naskah dan Klasifikasi Corrupt Manuskrip Mushaf al-Qur'an Koleksi Perpustakaan Pondok Pesantren Tebuireng
}

\author{
Adrika Fithrotul Aini \\ Institut Agama Islam Negeri (IAIN) Tulungagung \\ adrikaaini01@gmail.com
}

DOI: $10.29240 /$ alquds.v4i1.1173

Submitted: 2019-10-31 | Revised: 2020-03-19| Accepted: 2020-04-15

\begin{abstract}
This study focused on the Qur'anic mushaf manuscript, the heritage collection of KH. Hasyim Asy'ari, stored in the library of Tebuireng pesantren. In this Pesantren, there are many collections of manuscripts, but this Qur'anic manuscript is never discussed bythe researchers who scrutinize KH. Hasyim Asy'ari's collection works. The present study had three stages, namely identification of manuscript, criticism of corrupt texts, and the form of scholia manuscript. The purposes of this study were to explain the identity of the manuscript and classify the corrupt and scholia forms that occurred in the Qur'anic manuscript at Tebuireng Pesantren.The method used was the criticism of the texts through the inventory of all faults that occurred in the copying based on the Qur'anic manuscript that had been in tashih. This study found out that (1) the manuscript of the Qur'anicmushaf, the heritage collection of KH. Hasyim Asy'ari, had many mistakes in the process of copying. Frequent mistakes lied in punctuation errors, dots in letters, excess letters, or lack of letters; and (2) The Scholia manuscript form of the Qur'anicmushaf, the heritage of KH. Hasyim Asy'ari, was used to give clarification on the mistakes that occurred in the texts. This is different from the scholia in the manuscripts of the Quran in Indonesia, which is commonly used for maqra' and the Ju\%:
\end{abstract}

Keywords: Manuscript identification, Qur'anic Mushaf, Corrupt text, and Scholia form.

Abstrak. Penelitian ini fokus pada naskah (manuskrip) mushaf al-Qur'an warisan
koleksi KH.Hasyim Asy'ari yang tersimpan diperpustakaan Pondok Pesantren
Tebuireng.Di Perpustakaan Tebuireng terdapat banyak koleksi manuskrip, namun
manuskrip mushaf al-Qur'an ini tidak pernah dibahas oleh para peneliti yang mengkaji
mengenai karya koleksi KH. Hasyim Asy'ari. Penelitian ini akan membahas tiga hal,
yakni identifikasi naskah, kritik teks corrupt, dan bentuk scholia naskah. Adapun tujuan
penelitian ini adalah menjelaskan mengenai identitas naskah dan mengklasifikasikan
bentuk corrupt dan scholia yang terjadi pada naskah al-Qur'an di Pondok Pesantren
Tebuireng. Metode yang digunakan adalah kritik teks, melalui inventarisasi segala
kesalahan yang terjadi dalam penyalinan yang didasarkan pada naskah mushaf al-Qur'an
yang sudah ditashih. Hasil penelitian ini menemukan, bahwa (1) Naskah mushaf al- 
Qur'an warisan KH. Hasyim Asy'ari ini memiliki banyak kesalahan dalam proses penyalinan. Kesalahan yang sering terjadi terletak pada kesalahan tanda baca, titik dalam huruf, kelebihan huruf, atau kekurangan huruf; dan (2) Penggunaan bentuk scholia naskah mushaf al-Qur'an warisan KH. Hasyim Asy'ari digunakan untuk memberikan klarifikasi atas kesalahan yang terjadi dalam teks. Hal ini, berbeda dengan bentuk Scholia dalam manuskrip-manuskrip mushaf al-Qur'an di Indonesia yang umumnya digunakan untuk penulisan maqra' dan nama juz.

Keyword: Identifikasi naskah, Mushaf al-Qur’an, Corrupt, Scholia.

\section{Pendahuluan}

Manuskrip adalah suatu warisan budaya yang di dalamnya mengandung makna tersendiri.Makna dalam naskah dapat ditemukan dalam bentuk tulisan, iluminasi, ilustrasi, dan bentuk lainnya yang ada dalam suatu naskah (Gacek, 2009; Permadi, 2012; Bausi, 2015).Naskah mushaf al-Qur'an sudah ada di Nusantara sejak akhir abad ke-13 H. Penyalinan mushaf al-Qur'an tersebut mempunyai makna masing-masing baik dari segi tulisan maupun simbol-simbol yang ada dalam naskah.Menurut sejarah, penyalinan mushaf al-Qur'an dilakukan sampai menjelang akhir abad ke-19. ${ }^{1}$

Penyalinan mushaf al-Qur'an banyak dilakukan di berbagai daerah. Hal ini ditunjukkanya, setiap daerah di wilayah Indonesia hampir semua ditemukan naskah mushaf al-Qur'an, salah satunya adalah naskah mushaf al-Qur'an koleksi perpusatakaan Pondok Pesantren Tebuireng.Pesantren Tebuireng mempunyai koleksi naskah-naskah kuno yang disinyalir naskah disalin K.H. M. Hasyim Asy'ari.Beberapa naskah yang disalin berbicara mengenai tasawuf, fiqih, hadits, dan mushaf al-Qur'an.

Penelitian mengenai naskah mushaf al-Qur'an selama ini belum banyak dilakukan di Indonesia, terutama dari aspek corrupt dan scholia. Dalam beberapa hasil penelitian, penelitian terhadap naskah mushaf al-Qur'an pernah dilakukan oleh Mustofa (2013), dia melakukan penelitian naskah mushaf al-Qur'an dari segala bentuk simbol dan variasi dalam naskah. Tulisan ini mengungkap mengenai segala simbol yang ada dalam catatan pinggir naskah (scholia), akan tetapi ia tidak menjadikan bentuk scholia sebagai simbol yang mempunyai makna yang berhubungan dengan teks. Kemudian, Ali Akbar (2014) dalam pembacaan al-Qur'an lebih spesifik pada aspek iluminasi di wilayah Sulawesi Barat.Adapun kajian secara isi teksnya pernah dilakukan oleh Tati Rahmayani (2017), dia berbicara mengenai karakter mushaf al-Qur'an di Madura. Tati dalam tulisannya sudah menyinggung mengenai segala bentuk kesalahan yang terjadi dalam

${ }^{1}$ Faizin, Sejarah Percetakan Al-Qur'an (Yogyakarta: Era Baru Pressindo, 2012). Lihat juga dalam Kementrian Agama, Keindahan Mushaf Al-Qur'an Kuno Nusantara (Jakarta: Lajnah Pentashihan Mushaf al-Qur'an Badan Litbang dan Diklat Kementrian Agama RI, 2015). 
naskah mushaf al-Qur'an Madura, akan tetapi ia tidak menjadikan segala kesalahan tersebut sebagai data untuk menganalisis lebih jauh karakter naskah tersebut.

Penelitian ini akan menjelaskan mengenai identifikasi naskah yang berkaitan dengan judul, kondisi penyimpanan, bentuk tulisan, serta mengungkap sejarah hubungan naskah tersebut dengan konteks pondok pesantren Tebuireng. Selain itu, Penelitian ini juga akan memaparkan mengenai klasifikasi bentuk corrupt yang terjadi dalam penyalinan naskah dan bentuk scholia yang digunakan penyalin sebagai metode emendasi dalam menyikapi kesalahan yang ada di dalam teks. Untuk mengungkap hal tersebut, penulis menggunakan metode kritik teks dengan cara melakukan inventarisasi segala kesalahan yang terjadi dalam penyalinan yang didasarkan pada naskah mushaf al-Qur'an yang sudah ditashih kebenaran tulisannya. Kemudian, penulis melakukan klasifikasi setiap kesalahan berdasarkan kategori yang ada dalam pembagian corrupt yang dibuat oleh Baroroh Baried, yakni haplografi, ditografi, dan kesalahan huruf atas. Setelah itu, penulis melakukan pembacaan terhadap scholia,yang mana scholia bukanlah hanya hiasan pinggir teks, akan tetapi scholia bisa digunakan sebagai data untuk menganalisis kesalahan-kesalahan yang ada dalam suatu teks.

\section{Identifikasi Naskah}

\section{Judul dan Penyalin Naskah}

Naskah mushaf ini tanpa judul. Naskah ini merupakan naskah mushaf al-Qur'an yang disinyalir merupakan naskah mushaf milik koleksi Mbah Hasyim Asy'ari. ${ }^{2}$ Di bagian sampul ada bekas tulisan pegon, dan kemungkinan ada disebut siapa penyalin mushaf tersebut. Namun, karena kondisi naskah yang sudah rusak maka tulisan tersebut tidak terbaca. Di bagian belakang pun tidak ada semacam kolofon. Sehingga, penulis menyebut naskah ini adalah naskah koleksi perpustakaan Pondok Pesantren Tebuireng.

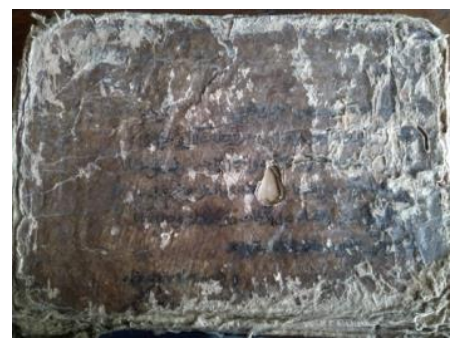

Gambar 1. Sampul Bertuliskan Arab Pegon

${ }^{2}$ Wawancara dengan salah satu pengasuh Pondok Tebuireng pada tanggal 25 Juli 2019. 
Apabila melihat karya-karya lain dari tulisan Mbah Hasyim Asy'ari, mayoritas kitab-kitabnya ditulis pada saat beliau sudah mendirikan Pesantren Tebuireng dan berdirinya Nahdhatul Ulama. Hal ini bisa dilihat dari kitab atTibyan fi Nabyi an Muqhotho'atil Arbami wal Ibwan yang dalam muqaddimahnya tertera tulisan:

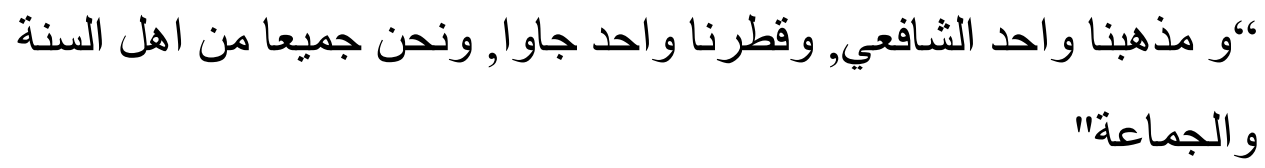

Kitab tersebut ditulis pada 25 Sya'ban tahun 1346 H/1925 M. Selain itu, kitab Ziyadatut Ta'liqat juga tertera ditulis pada tahun $1352 \mathrm{H}$. Kemudian, kitab Tanbihatul Wajibat tertera dalam kolofon ditulis pada tahun $1355 \mathrm{H}$. Ada juga tulisan Mbah Hasyim tentang wirid atau Hizb yang ditulis pada tahun $1359 \mathrm{H}$. Kitab Risalatul Taubidiyyah ditulis pada tahun 1362 H. Selain berbicara mengenai mayoritas karya Hasyim Asy'ari yang ditulis pada abad ke-19, indikator lain yang menunjukkan bahwa manuskrip mushaf ini bukan Hasyim Asy'ari yang menyalinnya adalah bentuk tulisan atau khat yang digunakan dalam bentuk tulisannya. Perbedaan dalam menggoreskan huruf 'hamzah kecil dalam kaf. Huruf hamzah kecil pada kaf dari tulisannya di mayoritas kitabnya memakai model khat naskhi biasa. Akan tetapi, pada manuskrip mushaf al-Qur'an yang dijadikan objek penelitian ini menggunakan bentuk huruf hamzah pada kaf seperti tulisan era tahun abad 18. Selain itu, goresan tulisan hamzah di atas ya' juga tidak sama seperti tulisan-tulisan Hasyim Asy'ari pada kitab yang lainnya. Selain itu, cara menuliskan lafadz basmalah juga berbeda. Dari beberapa data yang peneliti dapatkan tersebut, maka tulisan manuskrip mushaf al-Qur'an ini bukan tulisan Hasyim Asy'ari, namun menjadi koleksi perpustakaan pribadi beliau.

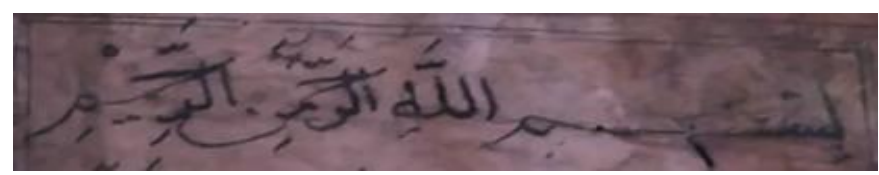

Gambar. 2 Lafadz Basmalah Naskah al-Qur'an

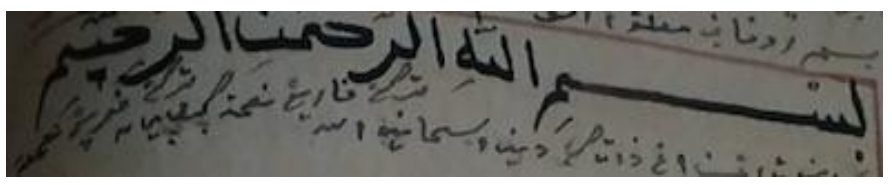

Gambar. 3 Lafadz Basmalah Tulisan Asli KH. Haysim Asy’ari

2. Nomor Naskah 
Naskah ini tidak memiliki nomor koleksi. Naskah ini disimpan di ruang private room dan tidak menyatu dengan koleksi-koleksi lain. Sehingga, naskah ini tidak bisa diakses oleh semua pengunjung. Apabila ingin melihat koleksi manuskrip hasil tulisan atau koleksi mbah Hasyim harus meminta izin ke penjaga perpustakaan yang bernama Ustadz Zainal. Alasan naskah ini tidak diberi label nomor karena menurut pemaparan penjaga perpustakaan bahwa naskah ini merupakan warisan Mbah Hasyim dan koleksi Mbah Hasyim merupakan koleksi kitab langka. sehingga, perpustakaan memberikan ruang tersendiri untuk koleksi Mbah Hasyim yang diambil dari perpustakaan pribadinyasebagai wujud cara pengelola perpustakaan memelihara warisan atau peninggalan beliau. ${ }^{3}$

\section{Tempat Penyimpanan Naskah}

Naskah mushaf al-Qur'an ini disimpan di perpustakaan dalam pondok pesantren Tebuireng. Naskah ini tidak disimpan di lemari khusus manuskrip, akan tetapi lemari kayu berkaca biasa. Pembeda dari koleksi lainnya hanya ruangannya. Manuskrip naskah ini tersimpan di ruang khusus yang bercampur dengan beberapa koleksi buku masa perpustakaan awal berdiri. Perpustakaan ini berdiri ketika masa K.H. Wahid Hasyim. Sedangkan Pondok Pesantren Tebuireng berdiri ketika tahun $1899 \mathrm{M}$.

Pondok Pesantren Tebuireng berada di Desa Tebuireng, yang menurut sejarah dulu desa ini bernama kebo ireng, yakni menggambarkan sosok kerbau yang sempat menghebohkan masyarakat karena warna kulitnya hitam. Mbah Hasyim yang awalnya tinggal di Desa keras bersama orang tuanya. Kemudian, Mbah hasyim hijrah ke Tebuireng karena pada masa kolonial dan berdirinya pabrik Gula Tjoekir, masyarakat sekitar sana suka minum-minuman keras dan suka perampokan. Beberapa hal tersebutlah yang mendorong Mbah Hasyim mendirikan Pondok Pesantren di daerah Tebuireng untuk berdakwah.

Manuskrip mushaf ini dan manuskrip lainnya tidak penah dirawat dan dibersihkan. Sebagaimana yang dijelaskan oleh penjaga perpustakaan bahwa naskah-naskah yang didapatkan dari ndalem kesepuhan semua ditaruh di ruang private dan jarang orang pernah menyentuhnya. Dari pengakuan penjaga perpustakaan pun mengatakan bahwa penjaga perpustakaan saja jarang menyentuh koleksi yang ada di ruang khusus tersebut.

Penjelasan dari penjaga perpustakaan mengatakan bahwa sebelum perpustakaan yang bernama A. Wahid Hasyim ini berdiri, koleksi naskah Mbah Hasyim berada di ndalem kasepuban dan berada di beberapa rak. Kemudian,

${ }^{3}$ Wawancara dengan Pak Zainal, pada tanggal 19 Juli 2019, pukul 12.00 WIB. 
setelah datangnya Gus Ishomuddin Hadziq yang merupakan cucu dari Mbah Hasyim merasa bahwa koleksi ini peninggalan Mbah Hasyim dan harus diselamatkan dan dirawat. Semenjak hadirnya Gus Ishom itulah koleksi perpustakaan bertamabah dengan dipindahnya koleksi di ndalem kasepuhan ke gedung perpustakaan di utara rumah. Perpustakaan A. Wahid Hasyim ini sudah berdiri sejak masa K.H. Wahid Hasyim yakni pada tahun $1936^{4}$, namun tulisan dan koleksi kitab Mbah Hasyim masih berada di ndalem kasepuhan.

Stereotype tentang manuskrip kuno sebagai sesuatu yang harus disimpan tanpa ada yang berani menyentuhnya itu masih sangat mengakar kuat dalam pondok pesantren ini. Hal ini sebagaimana yang dikatakan oleh Ustadz Zainal bahwa hanya Gus Ishom yang berani membuka kitab-kitab di ndalem kasepuban ketika itu dan melakukan penggandaan untuk disebarluaskan ke khalayak umum. $^{5}$

\section{Asal Naskah}

Naskah mushaf al-Qur'an koleksi perpustakaan pondok pesantren Tebuireng berasal dari koleksi pribadi Mbah Hasyim Asy'ari. ${ }^{6}$ Sehingga, dapat disebutkan jika naskah ini adalah hibah peninggalan Mbah Hasyim Asy'ari. Naskah ini tidak diketahui secara pasti dari mana asalnya. ${ }^{7}$

Di akhir naskah manuskrip mushaf ini tidak ada keterangan asal naskahnya, akan tetapi terdapat suatu tulisan yang berisi doa. Sepenggal doa yang dapat terbaca tersebut berbunyi:

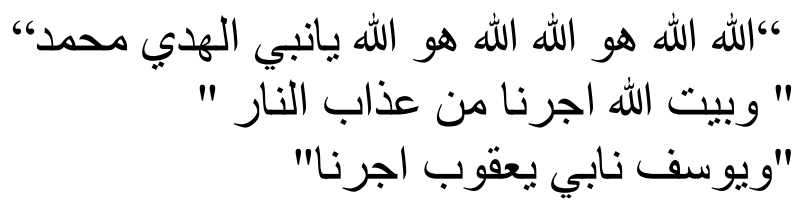

Tulisan di akhir naskah ini tidak menunjukkan informasi mengenai asal naskah, akan tetapi seperti doa atau mantra yang berlandaskan pada nama-nama Nabi.

Dalam buku filologi, dikatakan bahwa di Nusantara penyalinan naskah itu tidak ada hubungannya sama perdagangan. Naskah manuskrip mushaf ini peneliti mengidentifikasi bukan tulisan Mbah Hasyim Asy'ari. Hal ini dikarenakan menurut pemaparan narasumber yang peneliti lakukan wawancara

4 A. Mubarok Yasin, Profil Pesantren Tebuireng (Jombang: PustakaTebuireng, 2011), 196.

${ }^{5}$ Ibid.

${ }^{6}$ Perpustakaan Tebuireng didirikan sejak 1936, namun koleksi naskah ini masih berada di ndalem kasepuban. Lihat Ibid.

7 Wawancara dengan Pak Zainal yang merupakan penjaga Perpustakaan pertama kali di Pondok Pesantren Tebuireng. Beliau juga saksi langsung terjadinya perpindahan buku dan kitab koleksi Mbah Hasyim di rumahnya ke perpustakaan Tebuireng. 
dikatakan bahwa pada masa Mbah Hasyim dahulu, sering banyak kunjungan antar kyai ke ndalem kasepuban. Sehingga sangat memungkinkan juga bahwa naskah manuskrip mushaf tersebut adalah pemberian sesama kyai atau juga seorang santri. Atau semenjak berdirinya perpustakaan di dalam pondok pesantren, banyak kolega K.H. Wahid Hasyim yang berkunjung ke perpustakaan tersebut, di antaranya adalah Menteri Agama Mukti Ali. ${ }^{8}$

Peneliti mengasumsikan dengan beberapa alasan, di antaranya dari bentuk tulisan yang digunakan, tulisan dalam manuskrip mushaf ini cara menulisnya sangat berbeda dengan tulisan-tulisan di kitab-kitab Mbah Hasyim Asy'ari yang lainnya. sehingga, peneliti menyimpulkan bahwa tujuan dilakukan penyalinan mushaf ini adalah tujuan pendidikan agama pada era tertentu.

Beberapa perbedaan tulisan dalam manuskrip mushaf ini dengan tulisan mbah Hasyim lainnya adalah seperti gambar 4:

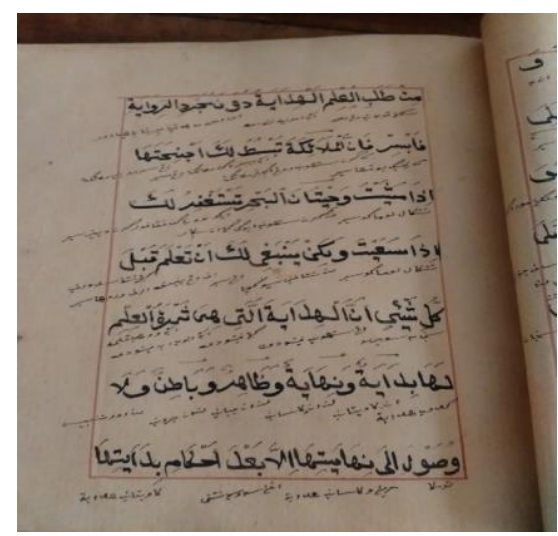

Gambar 4. Kitab Bidayatul Hidayah Tulisan Mbah Hasyim Asy'ari

\section{Keadaan Naskah}

Maksud dari keadaan naskah adalah wujud fisik suatu naskah. Beberapa hal yang dipakai untuk mendeskripsikan keadaan naskah adalah kondisinya yang utuh atau tidak, baik atau rusak. Dari hasil observasi peneliti, naskah manuskrip mushaf koleksi perpustakaan Tebuireng ini adalah naskah yang tidak utuh. Naskah ini tidak lengkap sebagaimana naskah mushaf al-Qur'an yang memuat 30 juz ayat-ayat al-Qur'an.

Manuskrip mushaf koleksi perpustakaan Tebuireng ini hanya memuat surat-surat al-Qur'an pilihan. Meskipun hanya surat-surat pilihan yang ada, namun ada beberapa lembar dari naskah tersebut yang rusak dan hilang karena

\footnotetext{
${ }^{8}$ Wawancara dengan Ahmad Fauzan, pada tanggal 30 Juli 2019.
} 
lepas dari jilidannya. Sehingga, sebagaimana dalam teori filologi yang dimaksud dengan naskah utuh adalah naskah yang keadaannya sempurna seperti semula, yaitu lengkap dalam arti tidak ada lembaran yang hilang dan keadaanya baik, penulis dapat mengatakan bahwa naskah ini tidak utuh dan rusak.

Jilidan yang menggunakan benang sudah banyak yang terlepas. Sehingga, sangat memungkinkan hilangnya beberapa lembaran naskah tersebut hilang atau rusak karena jilidan yang terlepas. Beberapa lembar yang hilang adalah: halaman

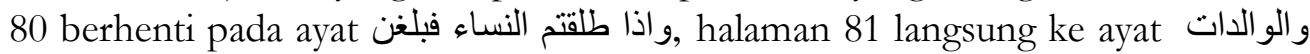

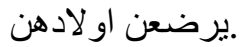

Selain naskah manuskrip ini tidak utuh, naskah ini juga mengalami kerusakan. Naskah yang rusak adalah naskah yang lembaran baik sebagian maupun keseluruhan terjadi sesuatu yang menyebabkan naskah tersebut tidak bisa dibaca. Naskah manuskrip mushaf al-Qur'an ini bisa dikategorikan naskah yang rusak, karena banyak bagian yang mengalami sobek dan berlubang. Rusaknya naskah ini bisa disebabkan karena usia kertas dan cara penyimpanannya. Menurut analisis penulis bahwa naskah ini rusak faktor utamanya adalah karena usia dan tempat penyimpanan yang sangat memungkinkan lebih mempercepat kertasnya lapuk.

Apabila dibandingkan dengan naskah koleksi Mbah Hasyim Asy'ari yang lainnya, naskah ini bisa dibilang naskah yang paling lama dari segi usia. Naskah yang lainnya yang berbentuk kitab tauhid, adab, dan lainnya masih dalam keadaan utuh. Jilidannya tidak terjadi kerusakan atau lepas. Sehingga, masih bisa dibaca dengan jelas dan belum ada lembaran-lembaran yang hilang baik karena jilidan maupun karena kondisi kertas yang semakin lapuk.

Kertas yang digunakan dalam manuskrip mushaf ini menggunakan alas Dluwang. Sedangkan naskah-naskah koleksi lainnya sudah menggunakan kertas produksi modern, meskipun tulisannya juga masih menggunakan tulisan tangan. Sehingga, beberapa tahun kemudian naskah-naskah lain yang terdapat di perpustkaan tersebut juga akan mengalami percepatan kerusakan yang sama apabila cara penyimpanan dan perawatannya masih sama dan tidak ada perhatian khusus untuk merawat naskah manuskrip peninggalan koleksi Mbah Hasyim di perpustakaan tersebut.

\section{Ukuran dan Tebal Naskah}

Ukuran halaman yang dimaksud adalah ukuran panjang, lebar dan tebal manuskrip. Ukuran panjang dan lebar halaman penulis bagi menjadi tiga bagian, pertama, panjang dan lebar halaman manuskrip secara utuh. Kedua, panjang dan lebar halaman manuskrip yang digunakan untuk menulis. Ketiga, panjang dan lebar halaman tepi yag tidak digunakan untuk menulis. 
Apabila melihat ukuran naskah mushaf ini, dapat dibagi menjadi dua, yakni ukuran lembaran naskah dan ukuran ruang tulisan atau teks. Naskah manuskrip mushaf ini termasuk naskah kuno yang berukuran sedang. Ukuran naskahnya adalah panjang $20 \mathrm{~cm}$ dan lebar $13,5 \mathrm{~cm}$. Sehingga ukurannya adalah $13,5 \times 20 \mathrm{~cm}$ (Dluwang).

Ukuran ruang tulisan atau teksnya, manuskrip ini mempunyai panjang tulisan 14,5 cm dan lebar 9,5 cm. Apabila dituliskan sebagaimana dalam buku Identfikasi Naskah karya Emuch Hermansoemantri, teks manuskrip ini berukuran 9,5x14,5 cm. akan tetapi, tidak semua teksnya mempunyai ukuran yang sama. Ada beberapa bagian yang tulisan teksnya keluar dari garis, sekitar $1 \mathrm{~cm}$. sehingga ukuran teksnya adalah 9,5x15,5 $\mathrm{cm}$. Ada pula beberapa bagian yang ukuran teksnya menjadi $10 \times 14 \mathrm{~cm}$. Akan tetapi, sebagaimana mengacu dalam buku filologi, yang menjadi patokan adalah ukuran yang mayoritas ada dalam teks keseluruhan manuskrip tersebut. Sehingga, dari hasil identifikasi ukuran secara keseluruhan, ukuran mayoritas teks naskah ini adalah 9,5x14,5 cm. Beberapa perbedaan ukuran dalam teks naskah tersebut difaktori oleh perbedaan ukuran tulisan. Ada beberapa lembar yang tulisannya berukuran lebih besar dari ukuran tulisan yang lainnya.

Naskah ini memiliki ketebalan yang tidak setebal mushaf al-Qur'an yang utuh 30 juz. Naskah manuskrip ini terdiri dari 212 halaman. Namun, ada dua halaman tambahan kosong di belakang. Naskah ini tidak bernomor halamannya, sehingga peneliti mengidentifikasi tebalnya dengan cara menghitungnya secara manual. Secara keseluruhan halaman-halaman pada manuskrip al-Qur'an koleksi perpustakaan Tebuireng ini memuat halaman pertama surat al-Fatihah dari awal dan diakhiri dengan surat al-Nas.

\section{Jumlah Baris dan Panjang Baris}

Tulisan dalam naskah ini memiliki jumlah baris rata-rata sekitar 9 baris. Akan tetapi ada bagian yang jumlah barisnya sebanyak 10 dan ada juga yang jumlahnya 11. Sebagaimana yang terdapat dalam lembaran yang dimulai dengan ayat واتقواله واعلموا ان الله بما تملون بصير Beberapa faktor yang menyebabkan perbedaan jumlah baris ini adalah panjangnya jarak atau spasi yang digunakan penulis mushaf tersebut. Ketika jumlah barisnya sebanyak 9 baris, maka ukuran spasi antar barisnya sekitar $1 \mathrm{~cm}$. Namun, apabila jumlah barisnya sebanyak 11 baris, maka ukuran spasinya adalah $0.1 \mathrm{~cm}$. Dengan demikian, jumlah baris dalam manuskrip mushaf ini mengalami ketidakkonsistenan. Ketidakkonsistenan tersebut bukan karena faktor kesengajaan penulis atau penyalin, akan tetapi ukuran spasi tulisan yang menyesuaikan dengan bingkai yang mengelilingi teks tersebut. 
Panjang baris yang dimaksud adalah panjang tulisan pada masing-masing halaman. Pengukuran panjang baris ini dilakukan secara variatif. Penulis tidak hanya mengukur satu baris saja dalam satu halaman, namun penulis mengukur panjang baris pada beberapa halaman yang memiliki panjang baris yang melebihi atau mengurangi panjang baris pada umumnya. Pengukuran panjang baris mengambil baris yang paling panjang dan paling pendek pada satu halaman, kemudian mengukur panjang baris pertama dan baris terakhir pada satu halaman. Setelah dilakukan pengukuran, rata-rata ukuran panjang baris berukuran $10 \mathrm{~cm}$.

\section{Huruf, Aksara, dan Tulisan}

Manuskrip mushaf ini menggunakan aksara Arab dengan khat Naskhi. Ukuran besaran khatnya adalah bervariasi, kecil dan besar. Besar ukuran hurufnya adalah sekitar $1 \mathrm{~cm}$. Apabila yang ukurannya lebih besar lagi, maka ukuran hurufnya sekitar $1,2 \mathrm{~cm}$. Manuskrip ini pun di dalamnya terdapat aksara pegon, akan tetapi peneliti tidak membaca tulisan tersebut dikarenakan kondisi naskah yang sudah lapuk, sehingga tulisannya tidak terbaca secara jelas.

Penulisan mushaf menggunakan khatsudah lumrah dipakai dalam peulisan mushaf di Nusantara, karena karakternya yang sederhana dan lebih mudah untuk dibaca. Akan tetapi, dalam mushaf koleksi perpustakaan pondok pesantren Tebuireng tidak secara penuh dan akurat mengacu pada pedoman penulisan khat. Hal ini dapat dilihat ketika menulis beberapa huruf tertentu, seperti wawu yang menjulur lurus dan tidak berlubang. Selain itu, ada juga penulisan yang tidak sesuai dengan kebiasaan khat Naskhi ${ }^{9}$, yakni pembubuhan titik untuk huruf zal yang ditulis bukan di atas ujung huruf, namun tepat di tengah, sehingga seperti tanda titik pada huruf nun. Sama halnya dengan hamzah di atas, titik dua ya' masih menyertai, yang mana ini sudah sangat jarang digunakan pada tulisan mushaf pada era Hasyim Asy'ari.

Khat yang digunakan dalam naskah ini memang menggunakan khat naskhi, akan tetapi kaidah huruf yang ada "renggetan" seperti huruf 'sin', 'syin', 'shad', dan terkadang pada huruf 'ta' 'ba' 'tsa' yang bersambung di tengah kalimat juga berbentuk seperti itu. Begitu juga dengan huruf ta' marbutboh di akhir kata yang bentuknya menyerupai alif yang ditambah dengan bulatan di bagian bawah.

Tulisan manuskrip ini dapat dibaca secara jelas dan mudah. Setiap hurufnya yang belum rusak masih bisa dibaca jelas karena kondisi tintanya pun masih jelas. Hanya saja, pada bagian sampulnya ada sebuah tulisan yang sama

${ }_{9}$ Hasyim Muhammad al-Bagdadi, Qawaid Al-Khat al-Arabi (Baghdad: Dar al-Nahdah, 1968).; Lihat juga dalam Didin Sirajuddin AR, Seni Kaligrafi Islam (Jakarta: Pustaka Panjimas, 1985). 
sekali tidak bisa terbaca, karena selain kondisi naskah yang rusak juga tintanya sudah memudar. Berbicara mengenai tinta, tulisan dalam manuskrip ini menggunakan bentuk tinta celup. Identifikasi naskah ini menggunakan tinta celup karena banyak tetesan tinta beberapa lembar dibagian samping ruang teks yang kosong. Selain itu, alas dluwang yang tergolong kasar, maka tinta yang paling efektif digunakan adalah tinta celup. Tulisan dalam manuskrip ini menggunakan dua tipe warna tinta, yakni warna hitam dan merah. Hitam untuk bidang tulisan, sedangkan merah untuk tanda ayat, tanda waqaf, dan tanda rubu'.

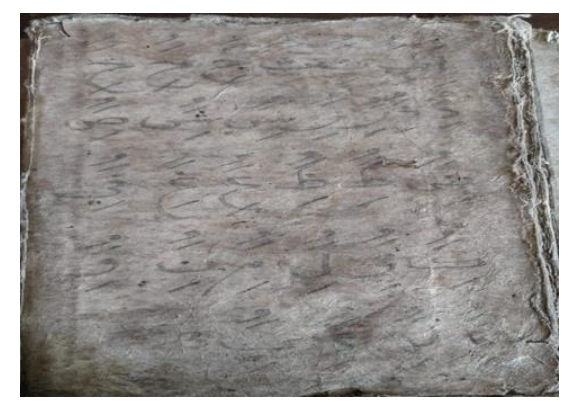

Gambar 5. Tulisan tinta yang pudar

Teks Al-Qur'an ditulis dengan khat naskhi dengan pena tebal. Terdapat tinta merah yang digunakan untuk lingkaran ayat (tanpa nomor), awal juz, dan menulis pembatas awal surah yang biasanya menjelaskan kategori surah makkiyah/madaniyah dan terkadang jumlah ayat dalam surah tersebut.

\section{Bahan Naskah}

Naskah manuskrip ini menggunakan alas Dluwang. Hal ini diidentifikasi dari alas yang digunakan serat-seratnya sangat terlihat dan tebal. Berbeda dengan koleksi naskah lainnya di perpustakaan tersebut yang banyak menggunakan kertas pabrik, bukan alas dengan pembuatan manual. Sehingga, serat-serat dari kayu pohon saeh masih sangat terlihat.

Dluwang adalah sejenis kertas yang terbuat dari kulit kayu pohon Papermulberry, Broussonetiapapyryfera Vent' yang pembuatannya dilakukan secara tradisional dengan teknologi serta peralatan yang sederhana, yaitu dengan cara ditumbuk, diperam, dan dijemur di terik sinar matahari. ${ }^{10}$ Ada pula yang menyebut "kertas kapas", sebab jika sudah lama dan lembab, serat-serat kulit kayu di bagian pinggir dluwangkadang-kadang terurai menjadi seperti kapas. Tetapi penyebutan "kertas kapas" tentu tidak tepat, karena tidak ada unsur serat

10 Tedi Permadi, “Asal-Usul Pemanfaatan dan Karakteristik Daluang: Bahan Naskah dalam Tradisi Tulis Nusantara - PDF Free Download,” adoc.tips, n.d., 6, https://adoc.tips/asalusul-pemanfaatan-dan-karakteristik-daluang-bahan-naskah.html. 
kapas, dan sesungguhnya itu adalah serat kulit kayu. ${ }^{11}$ Serat kulit kayu yang menyerupai kapas, penulis temukan pada naskah mushaf yang digunakan objek penelitian ini.

\section{Sejarah Naskah Mushaf al-Qur'an}

Tidak ada penjelasan terkait pemilihan surat-surat tertentu tersebut serta urutan-urutannya: dimulai Surah al-Fatihah, as-Sajdah, dan seterusnya kemudian ditutup Surah an-Nas. Namun, apabila dilihat dari bentuk tulisan mushaf alQur'an tersebut, mushaf ini mempunyai sejarah yang sangat erat dengan kehidupan pesantren.

Tebuireng merupakan pedukuhan yang termasuk wilayah administratif di Desa Cukir, Kecamatan Diwek, Kabupaten Jombang. Pondok ini berada pada kilometer 8 dari pusat kota Jombang. Pesantren ini berdiri pada penghujung abad ke-19. Pesantren ini berawal dari kegelisahan K.H. Hasyim Asy'ari atas bermunculannya pabrik-pabrik milik orang asing. Akan tetapi, munculnya pabrik-pabrik ini memberikan ketergantungan rakyat terhadapnya yang berdampak pada penjualan tanah-tanah rakyat. Selain itu, dampak lainnya adalah parahnya gaya hidup masyarakat yang jauh dari nilai-nilai agama.

Beberapa kondisi tersebut membuat K.H. Hasyim mendirikan sebuah bangunan kecil yang digunakan untuk rumah singgah dan tempat ngaji santri. Santri di pondok pesantren ini di era awal banyak berdatangan dari berbagai daerah, baik Jawa dan Madura. Banyaknya santri dari Madura ini juga difaktori oleh ucapan Kiai Kholil Bangkalan yang juga Guru Mbah Hasyim pernah memberi sinyal kepada masyarakat dan santrinya bahwa para Kiai di JawaMadura diisyaratkan untuk berguru kepada Kiai Hasyim. Hal ini terbukti, banyaknya santri datang dari Madura ke Tebuireng untuk berguru kepada beliau. $^{12}$

K.H. Hasyim pernah nyantri di berbagai daerah di Jawa Timur, seperti Surabaya, Tuban, Probolinggo, dan di Madura. Sebagaimaa, diketahui bahwa di wilayah Jawa Timur kaya akan manuskrip-manuskrip al-Qur'an maupun kitab tentang Islam, terutama di wilayah Madura. Apabila melihat runtutan sejarah Pondok Pesantren Tebuireng dan profil perjalanan ilmiah Mbah Hasyim,

\footnotetext{
${ }^{11}$ Ali Akbar, "Khazanah Mushaf Al-Qur'an Nusantara: Kertas/Alas Tulis," Khazanah Mushaf Al-Qur'an Nusantara, Jumat, Oktober 2012, http://qurannusantara.blogspot.com/2012/10/2-kertas.html. diakses pada 12 Mei 2019. Perihal kertas dluwang lihat, Titik Pudjiastuti, Naskah Dan Kajian Naskah (Bogor: Akademia, 2006), 36. Mutu kertas ini cukup baik, terbuktidari konsumennya yang bukan hanya Indonesia tetapi juga Belanda. Pusatpembuatan jenis kertas ini pada zaman dahulu terdapat di Garut (Jawa Barat),Ponorogo (Jawa Timur), dan Purwokerto (Jawa Tengah).

${ }^{12}$ Yasin, Profil Pesantren Tebuireng, 8.
} 
manuskrip mushaf al-Qur'an ini merupakan pemberian baik dari kolega maupun santri Kiai pada saat itu nyantri kepada beliau. Manuskrip ini bukan tulisan Mbah Hasyim, hal ini dikarenakan, bentuk tulisan dan usia naskahnya sebelum Mbah Hasyim mendirikan Pesantren.

Apabila melihat dari fungsi historisnya, manuskrip mushaf ini berfungsi sebagai pembelajaran al-Qur'an yang dilakukan seorang guru terhadap santrinya untuk menuliskan ayat al-Qur'an yang dihafalkannya. Indikasi ini dilatarbelakangi oleh faktor banyaknya kesalahan tulis dan adanya koreksian di samping tulisan yang salah maupun kurang lengkap. Dari berbagai data dan wawancara, pada masa Mbah Hasyim, orang nyantri bukan hanya dari kalangan anak muda, akan tetapi seorang Kiai pun nyantri kepada beliau. Beberapa hal tersebut, menurut peneliti mushaf al-Qur'an ini memang bukan tulisan Mbah Hasyim, dan manuskrip mushaf al-Qur'an adalah sebagai pembelajaran dalam menuangkan hafalannya dalam bentuk tulisan.

\section{Klasifikasi Corrupt dalam Naskah Mushaf al-Qur'an}

Corrupt adalah kesalahan. Kesalahan itu sesuatu yang sangat mungkin terjadi dalam penyalinan mushaf al-Qur'an. Kesalahan-kesalahan tersebut bisa berbagai bentuk, yakni kesalahan karena penulis atau kesalahan penyunting naskah karena kondisi naskah yang sudah rusak. Apabila kesalahan-kesalahan tersebut dikarenakan kesalahan penulis, maka bisa dikategorikan menjadi beberapa hal, yakni: haplografi (kurang komposisi kata), ditografi (penulisan dua kali), atau penyalinan yang salah karena komposisi kata yang sama. ${ }^{13}$

Secara umum, kesalahan dalam penulisan penyalinan mushaf al-Qur'an yang sering muncul adalah pada kesalahan tanda baca, titik dalam huruf, kelebihan huruf, atau kekurangan huruf. Di bawah ini akan dijelaskan beberapa bentuk corrupt yang ada pada manuskrip koleksi perpustakaan Tebuireng:

\section{Surat al-Fatihah dan Surat al-Baqarah}

\begin{tabular}{|l|l|}
\hline Kesalahan & Keterangan \\
\hline \multicolumn{1}{|c|}{$\begin{array}{l}\text { Awal Surat al-Baqarah } \\
\text { Hilang sampai ayat ke } \\
26\end{array}$} & Hilang huruf ya' karena kertas berlubang \\
\hline & Harena terlepas dari jilidannya. \\
\hline
\end{tabular}

13 Bisa dilihat di buku Siti Baroroh Baried, Pengantar Teori Filologi (Yogyakarta: Badan Penelitian dan Publikasi Fakultas Sastra Universitas Gadjah Mada, 1994), 60. 
32 | AL QUDS : Jurnal Studi Alquran dan Hadis vol. 4, no 1, 2020

\begin{tabular}{|c|c|}
\hline & Ada coretan penyalin \\
\hline الحو كيم & الحكيم ada kesalahan penyalin, karena ada bentuk coretan \\
\hline فلما انبأهم بأسمائهح & Kalimat ini hilang dari naskah. Terjadi haplogarafi \\
\hline sed & $\begin{array}{l}\text { Tulisan awalnya 'lam' tidak ada, tapi sama penyalin seperti } \\
\text { ditambahkan diakhir. }\end{array}$ \\
\hline ت ت تضرون & Salah huruf yang seharusnya تنظرون \\
\hline فيعلْمون & $\begin{array}{l}\text { فِتعلْمونُ } \\
\text { Adanya penambahan huruf "ta" }\end{array}$ \\
\hline 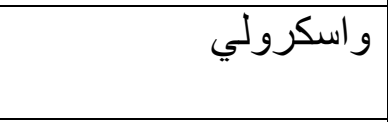 & ش ش و اشكرو الي \\
\hline 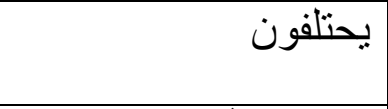 & $\begin{array}{l}\text { يختلفون } \\
\text { Adanya kesalahan penulisan }\end{array}$ \\
\hline خائيفين & Bukan akhir ayat, akan tetapi harusnya tanda waqaf \\
\hline $\begin{array}{l}\text { Ayat nomor } 143 \text { tidak } \\
\text { ada }\end{array}$ & Kesalahan penyalin yang terlewat \\
\hline تعملون & $\begin{array}{l}\text { ي يعملون } \\
\text { Adanya kesalahan penulisan }\end{array}$ \\
\hline 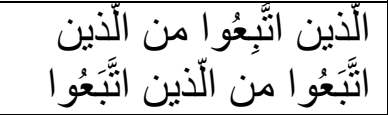 & Terjadi ditografi \\
\hline الاسنبابِ و قال & Harusnya akhir ayat. \\
\hline الحنزير & $\begin{array}{l}\text { الخنزير } \\
\text { Adanya kesalahan penulisan }\end{array}$ \\
\hline ولهم ولهم عذاب & Terjadi ditografi \\
\hline تحفيف & تخفيف \\
\hline 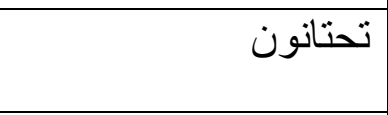 & $\begin{array}{l}\text { تختانون } \\
\text { Adanya kesalahan penulisan }\end{array}$ \\
\hline لباشن & سلباسُ \\
\hline 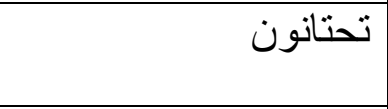 & $\begin{array}{l}\text { تختانون } \\
\text { Adanya kesalahan penulisan }\end{array}$ \\
\hline $\begin{array}{l}\text { Ayat } 199 \text { sampai } 204 \\
\text { terlewat }\end{array}$ & Ketidaksengajaan penyalin \\
\hline حتو ات & $\begin{array}{l}\text { خطوت } \\
\text { Adanya kesalahan penulisan }\end{array}$ \\
\hline 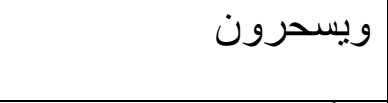 & $\begin{array}{l}\text { ويسخرون } \\
\text { Adanya kesalahan penulisan }\end{array}$ \\
\hline فانَّ به عليه & Lafadz الله terlewat \\
\hline
\end{tabular}




\begin{tabular}{|c|c|}
\hline وهو كره لكم و عسي انتيّو & 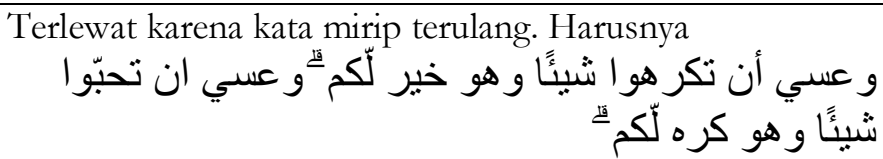 \\
\hline فاحو انكم & $\begin{array}{l}\text { فإخو انكم } \\
\text { Adanya kesalahan penulisan }\end{array}$ \\
\hline الطُاق & $\begin{array}{l}\text { الطلّق } \\
\text { Kekurangan kompisisi huruf (haplografi) }\end{array}$ \\
\hline فامثاك & $\begin{array}{l}\text { فإمسالك س Adanya kesalahan penulisan } \\
\text { Adany }\end{array}$ \\
\hline فان حفتم & فإن خفتم \\
\hline ان بنكح & $\begin{array}{l}\text { أن ينكحن } \\
\text { Penambahan huruf }\end{array}$ \\
\hline نصف & فنصف \\
\hline كثيرًا & $\begin{array}{l}\text { كثيرةً } \\
\text { Kesalahan tulisan }\end{array}$ \\
\hline 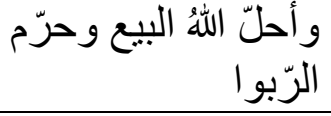 & Kalimat ini terlewat dari penyalinan \\
\hline احطئنا احسئ & $\begin{array}{l}\text { أخطئنا } \\
\text { Adanya kesalahan penulisan }\end{array}$ \\
\hline
\end{tabular}

\section{Surat al-Waqiah}

\begin{tabular}{|c|c|}
\hline Kesalahan & Keterangan \\
\hline حافظة & خافظة \\
\hline & Adanya kesalahan penulisan $\dot{\tau}$ \\
\hline الظُالْون & 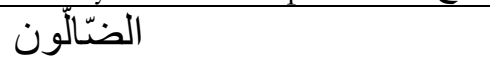 \\
\hline & ض Adanya kesalahan penulisan \\
\hline فساربون & $\begin{array}{l}\text { ش فنشاربون } \\
\text { Adanva kesalahan penulisan }\end{array}$ \\
\hline
\end{tabular}

\section{Surat Yasin}

\begin{tabular}{|c|c|}
\hline Kesalahan & Keterangan \\
\hline فاغشينتهم & $\begin{array}{l}\text { فأغشينه } \\
\text { Adanya penambahan huruf }\end{array}$ \\
\hline سفاعتهم & $\begin{array}{l}\text { شفعتهم Adanya kesalahan penulisan } \\
\text { Ad }\end{array}$ \\
\hline
\end{tabular}


34 | AL QUDS : Jurnal Studi Alquran dan Hadis vol. 4, no 1, 2020

\begin{tabular}{|c|c|}
\hline بسكرون & ش بشكرون \\
\hline سغلٍ & ش شَلٍ \\
\hline الاحضر & $\begin{array}{l}\text { الأخضر } \\
\text { Adanva kesalahan penulisan }\end{array}$ \\
\hline
\end{tabular}

\section{Surat ar-Rabman}

\begin{tabular}{|c|c|}
\hline Kesalahan & Keterangan \\
\hline والتّجم والشّجمر بسجدان & Kalimat terlewat karena kesalahan Penyalin \\
\hline النّحل & $\begin{array}{l}\text { النّخل } \\
\text { Adanya kesalahan penulisan }\end{array}$ \\
\hline 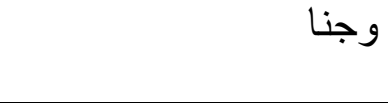 & $\begin{array}{l}\text { ي } 9 \text { Adanya kesalahan penulisan } \\
\text { وجى }\end{array}$ \\
\hline طمسـهن & 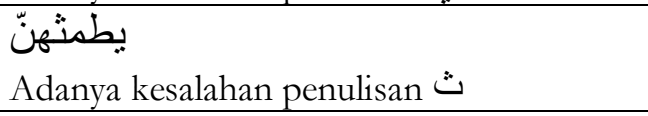 \\
\hline و نحل & 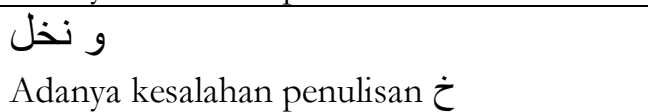 \\
\hline
\end{tabular}

\section{Surat al-Insan}

\begin{tabular}{|c|c|}
\hline Kesalahan & Keterangan \\
\hline $\begin{array}{l}\text { Setelah lafadz"،رون" يرون } \\
\text { (ayat 13) terlewat sampai } \\
\text { ayat } 26\end{array}$ & Kelalaian penyalin \\
\hline اشر هم & س أسر هم \\
\hline
\end{tabular}

\section{Surat an-Naba'}

\begin{tabular}{|c|c|}
\hline Kesalahan & Keterangan \\
\hline حطابا & خطابا \\
\hline & Adanya kesalahan penulisan $\dot{\nearrow}$ \\
\hline
\end{tabular}

\section{Surat at-Takwir}

\begin{tabular}{|l|l|}
\hline Kesalahan & Keterangan \\
\hline \multirow{2}{*}{ رجم } & $\begin{array}{l}\text { Adanya kesalahan penulisan ج } \\
\end{array}$ \\
\hline
\end{tabular}

\section{Surat al-Balad}




\begin{tabular}{|l|l|}
\hline Kesalahan & Keterangan \\
\hline أدريلك أكريك & $\begin{array}{l}\text { Adanya kesalahan penulisan د } \\
\end{array}$ \\
\hline
\end{tabular}

9. Surat al-Lail

\begin{tabular}{|c|c|}
\hline Kesalahan & Keterangan \\
\hline لستّي & 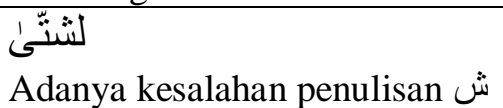 \\
\hline
\end{tabular}

\section{Scholia sebagai Counter Kesalahan dalam Naskah}

Scholia adalah sebuah teks yang ditulis oleh pengarang pada setiap halaman pinggir teks. Tulisan ini merupakan tulisan yang mempunyai korelasi dengan isi teks, baik digunakan untuk melakukan koreksi, keterangan tambahan, atau petunjuk lainnya. Scholia dalam manuskrip mushaf al-Qur'an digunakan untuk penulisan maqra' dan nama juz. Karakteristik scholia adalah ditulis secara horizontal dan berbeda dengan teks al-Qur'annya yang berbentuk vertikal. Dalam naskah mushaf al-Qur'an ini, scholia digunakan untuk memberikan klarifikasi atas kesalahan yang terjadi dalam teks. Adapun bentuk scholia tersebut adalah sebagai berikut:

\begin{tabular}{|c|c|}
\hline No. & Perbaikan atas Kekurangan Tulisan (Emendasi) \\
\hline 1. & فلما انبأهم بأسمائهم \\
\hline 2. & قو لا غير الذين قيل لهم فانزلنا على الذين ظلمو ا \\
\hline 3. & ان بؤمنو الكم وقد كان فريق منهم بيسعون \\
\hline 4. & خالدون الذين امنو و عملو الصالحات اولئك اصحاب الجنة هم فيها \\
\hline 5. & وماروت \\
\hline 6. & وحيث: \\
\hline 7. & يقتل \\
\hline 8. & الباءس \\
\hline 9. & ان تكر هو شيئا وهو خير لكم \\
\hline 10. & غير مديني ترجفونها ان كنتم \\
\hline 11. & تكذبان \\
\hline 12. & عينان نضاختان * فبائ الاء ربكما تكذبان \\
\hline 13. & ثم كلا سبعلمون \\
\hline 14. & ان الله \\
\hline 15. & ان بشـاء \\
\hline
\end{tabular}


36 | AL QUDS : Jurnal Studi Alquran dan Hadis vol. 4, no 1, 2020

\begin{tabular}{|c|c|}
\hline 16. & ثم ما ادريك ما يوم الدين \\
\hline 17. & مرقوم \\
\hline 18. & بل ران علي قلوبهم ما كنو ا يكسبون \\
\hline 19. & وجوه يو منذذ خاشعة \\
\hline 20. & ما الحطمة \\
\hline
\end{tabular}

\begin{tabular}{|c|c|}
\hline No. & Perbaikan atas Kesalahan Tulisan \\
\hline 1. & عصوا \\
\hline 2. & قل فلم \\
\hline 3. & تقاتلو هم \\
\hline 4. & 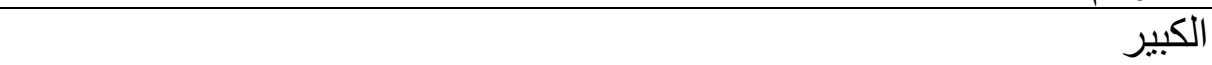 \\
\hline 5. & عدن \\
\hline
\end{tabular}

\begin{tabular}{|l|lr|}
\hline No. & Nama Juz & \\
\hline 1. & الجزؤ الثاني \\
\hline 2. & الجزؤ الثالث \\
\hline 3. & 14 اولثى \\
\hline
\end{tabular}

Scholia banyak ditemukan di surat al-Baqarah. Sedangkan, surat surat pendekseperti dalam juz 30 tidak ada sama sekali scholia yang berbentuk pembenaran atas kesalahan, kecuali scholia yang berbentuk penamaan juz dan tanda ruku'. Tanda ruku' ini ada yang mengistilahkan dengan maqra'. Menurut Zaenal Arifin mdzkur, maqra' adalah tanda yang dituliskan dengan huruf 'ain yang diletakkan di akhir ayat tertentu. ${ }^{14}$

Pembenaran atau koreksi dilakukan yang didasarkan atas kesalahan langsung pada saat menulis naskah, pembenaran kesalahan setelah naskah selesai ditulis, dan pembenaran kesalahan yang ditulis oleh pembaca berikutnya. ${ }^{15}$ Penulisan scholia dalam naskah mushaf al-Qur'an ini kemungkinan pembenaran tersebut pada aspek kesalahan penulis asli dan pembenaran setelah selesai

${ }^{14}$ Zaenal Arifin Madzkur, "Harakat dan Tanda Baca Mushaf Al-Qur'an Standar Indonesia dalam Perspektif Ilmu Dabt," SUHUF Jurnal Pengkajian Al-Qur'an dan Budaya 7, no. 1 (2014): 1-23, doi:10.22548/shf.v7i1.20.

${ }^{15}$ Mazmur Sya'roni, "Ragam Penulisan Mushaf Kuno Di Riau," in Mushaf-Mushaf Kuno Indonesia (Jakarta: Puslitbang Lektur Keagamaan, 2005), 6-7. 
penulisan naskah. Hal ini bisa diidentifikasi dari perbedaan bentuk tinta yang digunakan berbeda dengan tinta pada teks ayat di dalam garis.

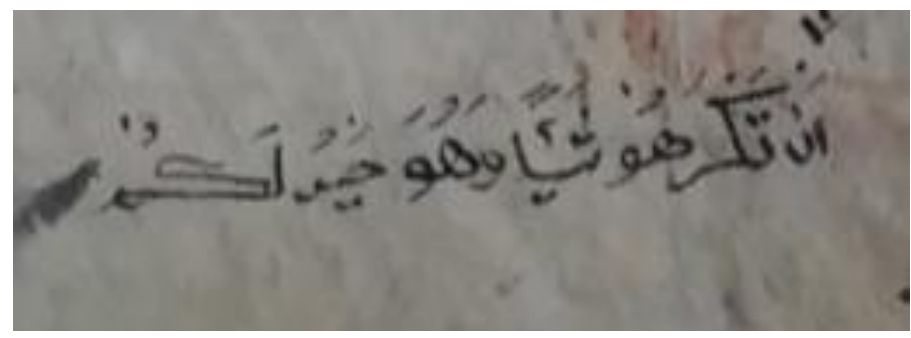

Gambar 6. Contoh Scholia yang memakai tinta lebih tipis

\section{Kesimpulan}

Berdasarkan pada penelitian di atas, naskah ini bukanlah naskah mushaf yang lengkap 30 juz, akan tetapi hanya surat-surat tertentu yang pada tradisi Pondok Pesantren surat-surat tersebut sebagai surat amalan keseharian para santri.Adapun corrupt yang ada dalam naskah ini adalah dalam bentuk ditografi, haplografi, dan kelalaian penulis. Dari klasifikasi di atas, dapat dilihat bahwa kesalahan banyak terjadi terhadap kesalahan atas penulisan huruf yang mempunyai bunyi huruf yang hampir sama, atau mempunyai makharijul huruf yang berdekatan. Sedangkan, bentuk scholia yang ada dalam naskah tersebut adalah ada dalam tiga hal, yakni pembetulan atas kekurangan tulisan, pembenaran atas kesalahan tulisan, dan nama juz.Scholia dalam naskah mushaf al-Qur'an koleksi perpustakaan Pesantren Tebuireng bukan hanya sebagai hiasan pinggir tanpa makna, akan tetapi scholia di sini berfungsi sebagai jawaban atas segala kesalahan tulis dalam naskah.

\section{Bibliografi}

Agama, Kementrian. Keindahan Mushaf Al-Qur'an Kuno Nusantara. Jakarta: Lajnah Pentashihan Mushaf al-Qur'an Badan Litbang dan Diklat Kementrian Agama RI, 2015.

Akbar, Ali. "Khazanah Mushaf Al-Qur'an Nusantara: Kertas/Alas Tulis." Khazanah Mushaf Al-Qur'an Nusantara, Jumat, Oktober 2012. http:/ / quran-nusantara.blogspot.com/2012/10/2-kertas.html.

Bagdadi, Hasyim Muhammad al-. Qawaid Al-Khat al-'Arabi. Baghdad: Dar alNahdah, 1968.

Baried, Siti Baroroh. Pengantar Teori Filologi. Yogyakarta: Badan Penelitian dan Publikasi Fakultas Sastra Universitas Gadjah Mada, 1994. 
38 | AL QUDS : Jurnal Studi Alquran dan Hadis vol. 4, no 1, 2020

Madzkur, Zaenal Arifin. "Harakat dan Tanda Baca Mushaf Al-Qur'an Standar Indonesia dalam Perspektif Ilmu Dabt." SUHUF Jurnal Pengkajian AlQur'an dan Budaya 7, no. 1 (2014): 1-23. doi:10.22548/shf.v7i1.20.

Permadi, Tedi. "Asal-Usul Pemanfaatan dan Karakteristik Daluang: Bahan Naskah dalam Tradisi Tulis Nusantara - PDF Free Download." adoc.tips, n.d. https://adoc.tips/asal-usul-pemanfaatan-dan-karakteristik-daluangbahan-naskah.html.

Pudjiastuti, Titik. Naskah Dan Kajian Naskah. Bogor: Akademia, 2006.

Sirajuddin AR, Didin. Seni Kaligrafi Islam. Jakarta: Pustaka Panjimas, 1985.

Sya'roni, Mazmur. "Ragam Penulisan Mushaf Kuno Di Riau." In Mushaf-Mushaf Kuno Indonesia. Jakarta: Puslitbang Lektur Keagamaan, 2005.

Yasin, A. Mubarok. Profil Pesantren Tebuireng. Jombang: PustakaTebuireng, 2011.

\section{Sumber Informan}

Ahmad Fauzan, pada tanggal 30 Juli 2019.

Pak Zainal, pada tanggal 19 Juli 2019. 